\section{JURNAL PENELITIAN}

Volume 25, Nomor 2, 2020 (124-134)

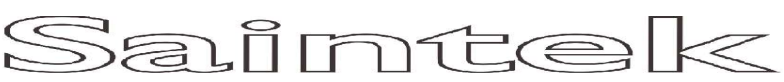

online: https://journal.uny.ac.id/index.php/saintek

\title{
PEMANFAATAN EKSTRAK DAUN URTICA DIOICA L. SEBAGAI ANTI-AGING ALAMI DALAM SEDIAAN KRIM
}

\section{(THE UTILIZATION OF URTICA DIOICA L. LEAVES EXTRACT AS A NATURAL ANTI-AGING IN CREAM PREPARATION)}

\author{
Siti Maimunah, Zuhairiah Nasution, dan Amila \\ Fakultas Farmasi dan Ilmu Kesehatan,Universitas Sari Mutiara Indonesia \\ Jl. Kapten Muslim No.79. Medan, 20123, Indonesia \\ email: siti_mai09@yahoo.com
}

\begin{abstract}
Abstrak
Penelitian ini bertujuan untuk memformulasikan ekstrak daun jelatang dalam sediaan krim dan menguji efektivitas anti-aging-nya. Penelitian ini dilakukan di Laboratorium Kimia Farmasi Universitas Sari Mutiara Indonesia pada bulan Juni-Agustus 2020. Alat yang digunakan adalah skin analyzer dan moisture checker. Sampel daun jelatang diperoleh dari Hutan Sibolangit, Sumatera Utara. Uji iritasi terhadap enam orang sukarelawan menggunakan krim ekstrak jelatang dengan konsentrasi tertinggi yaitu 0,5\%. Pengujian aktivitas anti-aging menggunakan 18 sukarelawan wanita berusia 19-22 tahun. Parameter yang diukur meliputi kadar air, jumlah pori dan kerutan. Distribusi data dianalisis dengan Shapiro-Wilk Test dan dilanjutkan dengan Kruskal-Walls Test dan Mann-Whitney Test. Hasil penelitian ekstrak etanol daun Jelatang dapat diformulasikan dalam bentuk sediaan krim tipe $\mathrm{A} / \mathrm{M}$ yang homogen, dengan $\mathrm{pH} 6$, viskositas $28.000 \mathrm{cps}$, tidak menimbulkan iritasi dan stabil dalam penyimpanan selama 28 hari. Hasil analisis dengan skin analyzer menunjukkan perubahan kondisi kulit menjadi lebih baik yaitu kadar air bertambah, pori dan kerutan berkurang. Sediaan krim dengan konsentrasi $0,5 \%$ menunjukkan efektivitas anti-aging terbaik.
\end{abstract}

Kata kunci: anti-aging, daun Jelatang, Urtica dioica L.

\begin{abstract}
This study was aimed at formulating Nettle leaf extract in a cream formulation and testing its anti-aging effectiveness. This research was conducted at the Pharmaceutical Chemistry Laboratory of Sari Mutiara Indonesia University in June-August 2020. The tools used were skin analyzer and moisture checker. Nettle leaf samples were obtained from the Sibolangit Forest, North Sumatra. The irritation test of six volunteers used nettle extract cream with the highest concentration of $0.5 \%$. The anti-aging activity test used 18 female volunteers aged 1922 years. Parameters measured include moisture content, number of pores and wrinkles. The data distribution was analyzed using the Shapiro-Wilk Test and followed by the Kruskal-Walls Test and the Mann-Whitney Test. The results show that the ethanol extract of Nettle leaves can be formulated in a homogeneous type A / $\mathrm{M}$ cream dosage form, with a $\mathrm{pH}$ of 6 , a viscosity of $28,000 \mathrm{cps}$, non-irritating and stable in storage for 28 days. The results of the analysis with the skin analyzer showed that the skin condition changed for the better, namely increased water content, reduced pores and wrinkles. Cream preparations with a concentration of $0.5 \%$ show the best anti-aging effectiveness.
\end{abstract}

Keywords: anti-aging, Nettle leaves, Urtica dioica L. 


\section{PENDAHULUAN}

Penuaan merupakan suatu proses yang sangat kompleks. Beberapa teori menjelaskan bahwa manifestasi seluler proses terjadinya penuaan juga dipengaruhi oleh faktor Reactive Oxygen Species (ROS) yang dihasilkan dalam sel. Jika terjadi ketidakseimbangan antara oksidan dan antioksidan dalam tubuh karena peningkatan ROS dan penurunan antioksidan dari dalam tubuh, menyebabkan kerusakan sel dan mempengaruhi penuaan pada kulit.

Dengan peningkatan efek insiden kerusakan suatu kulit oleh faktor pemicu terjadinya penuaan, perlu dilakukan strategi kemoprevensi dan pengembangan terapi dengan memanfaatkan ekstrak bahan alam. Mekanisme ekstrak bahan alam dalam melindungi kulit terdapat beberapa cara seperti reduksi reaktivitas dari ROS, menghambat proses oksidasi, menyerap sinar UV, mereduksi pembentukan kerutan pada kulit, dan melindungi kulit dari aging. Beberapa ekstrak tumbuhan dan antioksidan yang diperoleh dari sumber alami mampu mencegah penuaan dan meningkatkan kesehatan kulit (Pareetha \& Karthika, 2009).

Salah satu bahan alam yang dapat dikembangkan adalah tanaman jelatang (Urtica dioica L.). Ekstrak daunnya memiliki aktivitas antioksidan yang kuat (Saad \& Said, 2011) sehingga dapat digunakan lebih lanjut untuk membantu perawatan anti-aging kulit (Ferguson, 2011, p. 1).

Daun jelatang mengandung klorofil; protein; karotenoid seperti lutein, $\beta$ karoten, dan isomernya; mineral di antaranya zat besi, fosfor, magnesium, kalsium, potasium, sodium; vitamin B C, dan K (Zeipiṇa, Alsiña, \&Lepse, 2014); flavonoid seperti isokuersetin dan rutin, tannin, histamine, serotonin, asam format, asam resin, glukokinin (Jain, Singh, Parashar, \& Gupta, 2017); asam linoleat asam ursolik, neoxanthin, violaxanthin, likopen (Shailajan, Hande, Singh, \& Tiwari, 2014). Polisakarida, vitamin C, karoten serta flavonoid quercetin, rutin, kaempferol, dan beta-sitosterol (Rodriguez-Fragoso, Reyes-Esparza, Burchiel, Herrera-Ruiz, \& Torres, 2008). Daun Jelatang mengandung $14,4 \mathrm{mg} / 100 \mathrm{~g}$ tokoferol; $0,23 \mathrm{mg} / 100 \mathrm{~g}$ riboflavin; $13 \mathrm{mg} / 100 \mathrm{~g}$ besi; $0,95 \mathrm{mg} / 100$ g seng; $873 \mathrm{mg} / 100 \mathrm{~g}$ kalsium; $75 \mathrm{mg} / 100$ $\mathrm{g}$ fosfor; dan $532 \mathrm{mg} / 100 \mathrm{~g}$ kalium (Aksu \& Kaya, 2004). Ekstrak daunnya memiliki aktivitas antioksidan yang kuat (Saad \& Said, 2011) sehingga dapat digunakan lebih lanjut untuk membantu perawatan antiaging kulit (Ferguson, 2011, p. 1).

Penelitian ini memiliki tujuan khusus mengetahui esktrak daun jelatang yang diformulasikan sebagai krim anti-aging, konsentrasi terbaik dari krim ekstrak daun jelatang yang dapat memberikan efek antiaging yang stabil dalam penyimpanan. 


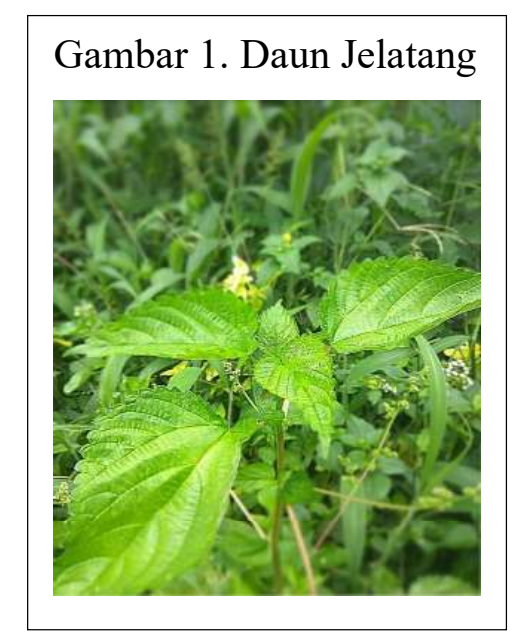

Urgensi penelitian ini adalah menurunkan ketergantungan terhadap bahan baku impor untuk produk kosmetika melalui pengembangan tanaman herbal, mengubah mindset masyarakat tentang tanaman jelatang yang dianggap beracun dengan membasmi tanaman jelatang padahal memiliki manfaat dibidang kesehatan dan pangan, mengembangkan variasi antioksidan dari sumber alami untuk mencegah penuaan dan meningkatkan kesehatan kulit.

Anti-aging adalah sediaan yang berfungsi yang menghambat proses kerusakan pada kulit (degeneratif) sehingga mampu menghambat timbulnya tanda-tanda penuaan pada kulit beberapa bahan yang terdapat pada produk anti-aging: Peptida, anti oksidan, vitamin C, vitamin E (Muliyawan \& Suriana, 2013, pp. 16-17).

Skin analyzer merupakan sebuah perangkat yang dirancang untuk mendiagno-sis keadaan kulit. Tambahan rangkaian sensor kamera yang terpasang pada skin analyzer menampilkan hasil dengan cepat dan akurat (Aramo, 2012, p. 24).

\section{METODE PENELITIAN}

Penelitian ini dilakukan di Laboratorium Kimia Farmasi Universitas Sari Mutiara Indonesia pada bulan Juni-Agustus 2020. Alat yang digunakan dalam penelitian ini adalah skin analyzer and moisture checker (Aram Huvis API-100), lumpang porselin, stamfer, cawan porselin, alat-alat gelas, spatula, pipet tetes, penangas air, $\mathrm{pH}$ indikator, dan neraca analitik (Dickson), rotary evaporator (Stuart), oven, viskometer Brookfield.

Bahan pembuatan krim adalah asam stearat, setil alkohol, natrium hidroksida, trietanolamin, nipagin, air suling, gliserin, ekstrak daun jelatang, metil biru, larutan dapar $\mathrm{pH}$ asam $(4,01)$, larutan $\mathrm{pH}$ netral $(7,01)$, dan etanol $96 \%$. Sampel daun jelatang yang digunakan dalam penelitian ini diambil secara purposive. Sampel daun jelatang diperoleh dari Hutan Sibolangit, Sumatera Utara. Identifikasi tumbuhan dilakukan di Herbarium Medanense.

Daun jelatang segar dibersihkan dari partikel asing, direndam dalam air, dianginanginkan, dikeringkan menggunakan lemari pengering, setelah kering sampel dihaluskan menggunakan blender hingga menjadi serbuk diayak dengan ayakan 61 mesh. Serbuk daun jelatang yang diperoleh 
diekstraksi menggunakan pelarut etanol $96 \%$ (1:10) selama 4 hari dengan pengadukan 1x24 jam. Ekstrak diuapkan menggunakan rotary evaporator pada $47^{\circ} \mathrm{C}$ dan $60 \mathrm{rpm}$. Penguapan filtrat disempurnakan kembali menggunakan oven dengan $70^{\circ} \mathrm{C}$ hingga diperoleh ekstrak kental(Mustikawati, 2017, p. 429).

Formula pembuatan dasar krim sebagai berikut: R/Asam stearat $20 \mathrm{~g}$, Setil alkohol $0.5 \mathrm{~g}$, Trietanolamin $1 \mathrm{~g}$, Natrium Hidroksida $0.2 \mathrm{~g}$, Gliserin $8 \mathrm{~g}$, Nipagin $0.1 \mathrm{~g}$, aquadest ad. Cara pembuatan krim adalah sebagai berikut. Asam stearat dan setil alkohol dimasukkan ke dalam cawan penguap dan dilebur di atas penangas air pada suhu $70^{\circ} \mathrm{C}$ (massa I). Natrium Hidroksida, gliserin, nipagin dan TEA dilarutkan di dalam air panas yang telah ditakar pada $70^{\circ} \mathrm{C}$ (massa II). Dimasukkan massa I ke dalam lumpang panas dan ditambahkan massa II ke dalamnya, gerus sampai terbentuk massa krim. Pada lumpang lain dimasukkan ekstrak daun jelatang, ditambahkan dasar krim gerus sampai homogen. Pemeriksaan terhadap sediaan krim meliputi: pemeriksaan Homogenitas, penentuan $\mathrm{pH}$ sediaan dilakukan menggunakan $\mathrm{pH}$ indikator, penentuan tipe emulsi sediaan dengan penambahan sedikit biru metil ke dalam sediaan dan pengamatan stabilitas sediaan.

Uji iritasi terhadap enam orang sukarelawan menggunakan krim ekstrak jelatang dengan konsentrasi tertinggi yaitu $0,5 \%$ dengan cara sediaan krim dioleskan di kulit punggung tangan membentuk lingkaran, lalu biarkan selama 24 jam, diamati setiap 4 jam sekali apakah terjadi iritasi kulit atau tidak.

Pengujian aktivitas anti-aging menggunakan sukarelawan sebanyak 18 orang, dengankriteria adalahwanitausia 19-22 tahun, tidak memiliki riwayat ber-kaitan dengan alergi kulit, bersedia dan menandatangani surat persetujuan ikut penelitian sampai selesai. Sukarelawan dibagi menjadi enam kelompok dengan masing-masing kelompok terdiri atas tiga orang sukarelawan yaitu keompok I (Kelompok A), kelompok II (Krim B), kelompok III (Krim C), Kelompok IV (Krim D), Kelompok V (Krim E), dan kelompok VI (Krim F).

Uji efektivitas anti-aging diawali dengan pengukuran kondisi kulit awal sukarelawan. Perawatan dilakukan pengolesan krim hingga merata seluas area yang ditandai, krim dioleskan berdasarkan kelompok yang ditetapkan di atas, pengolesan dilakukan sebanyak 2 kali sehari selama 4 minggu. Perubahan kondisi kulit diukur setiap minggu selama 4 minggu menggunakan skin analyzer. Parameter yang diukur meliputi kadar air, jumlah pori dan kerutan. Data yang diperoleh lalu dianalisa menggunakan aplikasi SPSS. Distribusi data dianalisis dengan Shapiro-Wilk Test dan 
dilanjutkan dengan Kruskal-Walls Test dan Mann-Whitney Test.

\section{HASIL DAN PEMBAHASAN}

Identifikasi sampel dilakukan di Herbarium Medanense (MEDA), Universitas Sumatera Utara. Hasilnya menunjukkan bahwa sampel yang digunakan adalah benar merupakan daun jelatang.

Hasil ekstraksi menggunakan pelarut ethanol 96\% untuk menarik senyawa yang terdapat dalam simplisia. Hasil ekstraksi dari 500 gram serbuk simplisia Urtica dioica $\mathrm{L}$. diperoleh ekstrak etanol daun jelatang 60,85 gram dengan hasil rendemen esktrak sebesar $12,17 \%$.

Pengamatan organolpetis sediaan krim ekstrak etanol daun jelatang meliputi warna, bau, dan konsistensi yang diamati secara visual. Sediaan dinyatakan stabil apabila warna, bau, dan konsistensi tidak berubah secara visual selama penyimpanan dan juga tidak ditumbuhi jamur dari hari pertama sampai 28 hari. Hasil pengamatan organoleptis sediaan krim ekstrak etanol daun jelatang menunjukkan bahwa semua sediaan krim tidak mengalami perubahan yang berarti dari segi penampilan baik warna, bau, dan konsistensinya selama penyimpanan 28 hari. Hal ini menunjukkan sediaan krim ekstrak etanol daun jelatang stabil. Hasil pengamatan organoleptis sediaan krim ekstrak etanol daun Jelatang dapat di lihat pada Gambar 3 dan Tabel 1.

Uji homogenitas bertujuan untuk melihat keseragaman partikel dalam sediaan krim. Untuk memenuhi syarat homogenitas parameternya adalah sebaran warna merata dan pemisahan fase tidak terjadi. Hasil pengamatan homogenitas dapat dilihat pada Gambar 4. Hasilnya menunjukkan bahwa semua sediaan krim homogen.

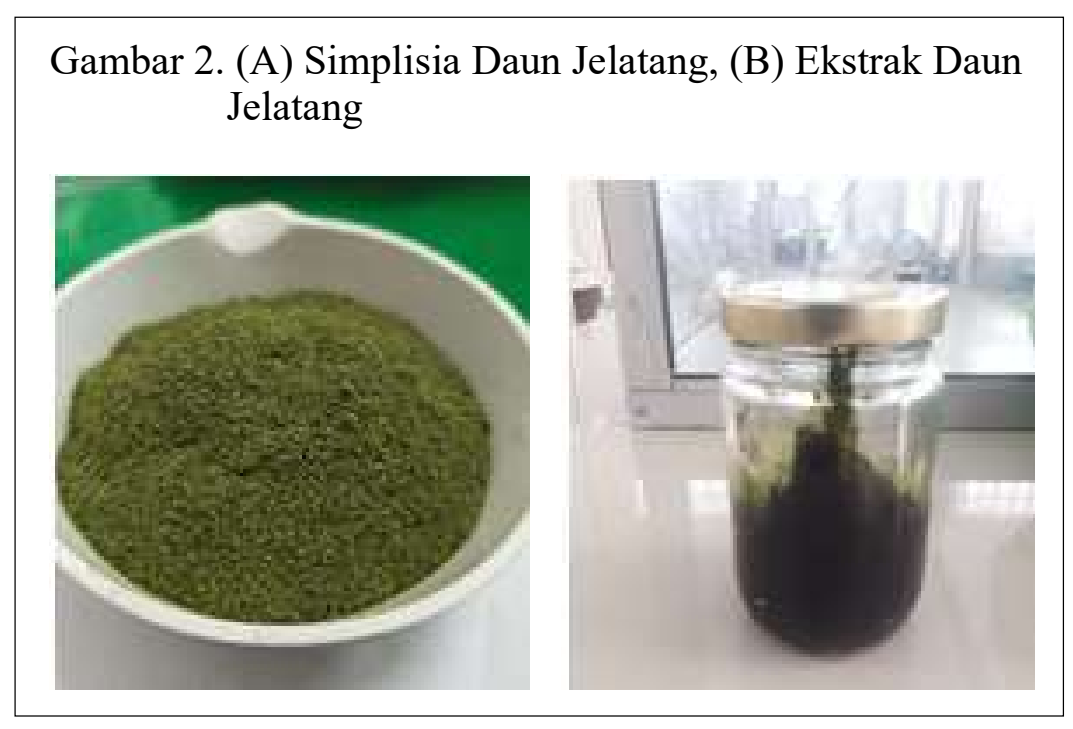


Gambar 3. (A) Krim (basis Dasar atau Blanko), (B) Krim yang Sudah Ditambah Ekstrak Daun Jalatang, (C) Krim yang Sudah Ditambahkan Ekstrak Daun Jelatang $0,2 \%, 0,3 \%, 0,4 \%$, dan $0,5 \%$
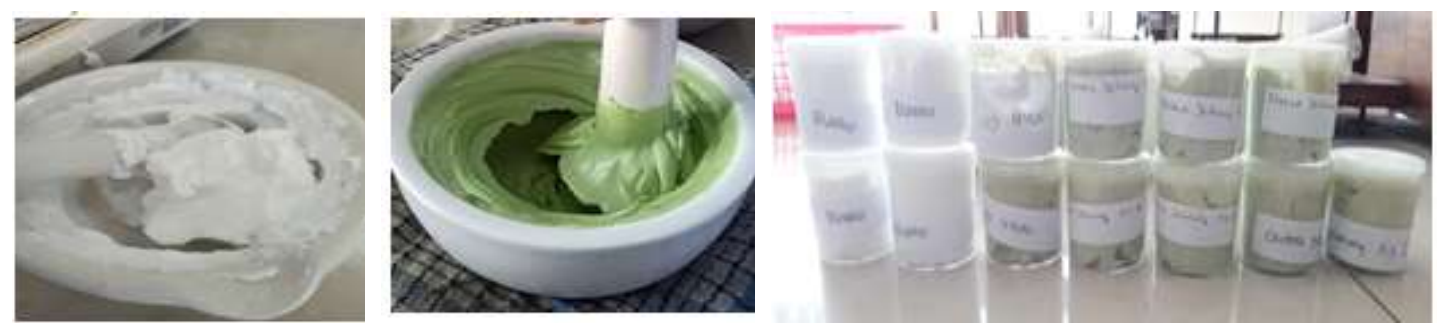

Tabel 1

Hasil Pengamatan Organoleptis Sediaan Krim

\begin{tabular}{lcccccc}
\hline Pengamatan & Krim A & Krim B & Krim C & Krim D & Krim E & Krim F \\
\hline Warna & Putih & Hijau & Hijau & Hijau & Hijau & Putih \\
& & Terang & Terang & Muda & Muda & \\
Bau & Tidak & Berbau & Berbau & Berbau & Berbau & Berbau \\
& berbau & khas & khas & khas & khas & wangi \\
Konsistensi & Semi solid & Semi solid & Semi solid & Semi solid & Semi solid & Semi solid \\
Homogenitas & Homogen & Homogen & Homogen & Homogen & Homogen & Homogen \\
pH & 6 & 6 & 6 & 6 & 6 & 6 \\
Tipe Emulsi & A/M & A/M & A/M & A/M & A/M & A/M \\
\hline
\end{tabular}

Keterangan: (A) Basis krim (blanko), (B), (C), (D), dan (E) Sediaan krim ekstrak etanol daun Jelatang dengan Konsenterasi Berturut-turut 0,2\%; 0,3\%; 0,4\%; dan 0,5\%; (F) Pembanding yang beredar di pasaran.

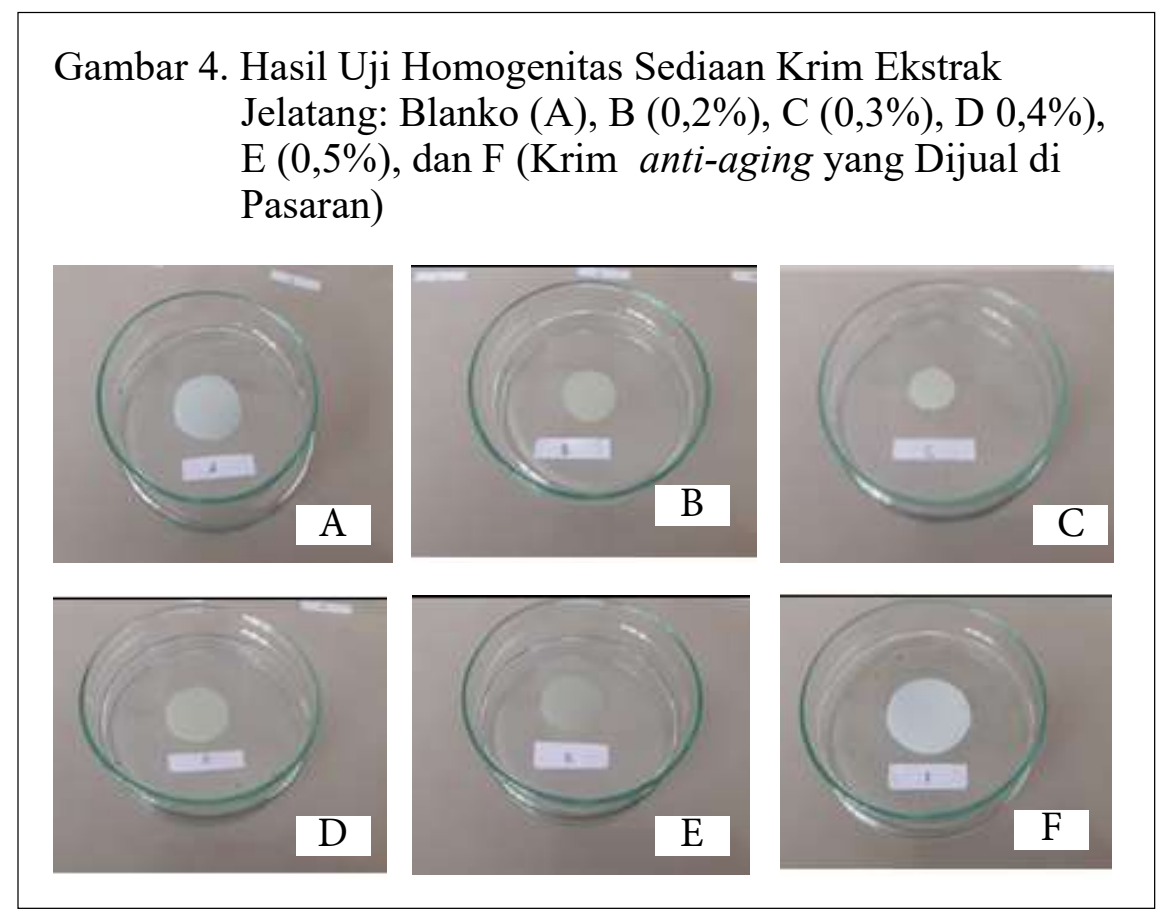


Penentuan $\mathrm{pH}$ sediaan dilakukan menggunakan alat $\mathrm{pH}$ indikator dengan tiga kali pengulangan. Berdasarkan hasil pengukuran $\mathrm{pH}$ yang diperoleh dari masing-masing $\mathrm{pH}$ sediaan krim formula basis krim (A), B $(0,2 \%), C(0,3 \%)$, D (0,4\%), E ( $0,5 \%)$, dan $\mathrm{F}$ (Pembanding yang beredar dipasaran) adalah $6, \mathrm{pH}$ sediaan krim yang dibuat masih memenuhi batas $\mathrm{pH}$ fisiologis kulit.

Pemeriksaan viskositas krim menggunakan viskometer brookfiled. Hasil pengujian viskositas untuk semua sediaan krim berada pada rentang 28.000-34.000 cps. Viskositas krim yang baik berkisar antara 2000-50000 (Martin, Awabrick, \& Cmmarat, 2012). Hal ini berarti viskositas sediaan krim yang diuji berada pada rentang viskositas yang baik.

Viskositas sediaan semi padat menjadi salah satu faktor yang perlu diperhatikan karena berkaitan dengan kenyamaan penggunaan. Krim harus mudah dioleskan dan dapat menempel pada kulit. Krim tidak boleh terlalu keras dan terlalu encer karena berkaitan dengan efek terapi yang diinginkan serta kenyamanan penggunaan (Shofyana \& Zulkarnain, 2013).

Sediaan krim yang dihasilkan diuji tipe emulsinya dengan menambahkan metilen biru. Hasilnya terlihat bahwa warna metilen biru tidak dapat tersebar merata pada krim sehingga dapat disimpulkan bahwa sediaan krim berjenis $\mathrm{A} / \mathrm{M}$. krim $\mathrm{A} / \mathrm{M}$ adalah krim yang fase luarnya adalah minyak. Krim berjenis ini meiliki beberapa keunggulan, diantaranya daya lekat yang lebih lama daripada krim tipe M/A dan pada umumnya orang lebih menyukai krim tipe $\mathrm{A} / \mathrm{M}$, karena penyebarannya lebih baik, walaupun sedikit berminyak tetapi penguapan airnya dapat mengurangi rasa panas di kulit (Rahmawati, Sukmawati, \& Indrayudha, 2015).

Krim pada penelitian ini menggunakan bahan aktif dari ekstrak daun jelatang. Salah satu kandungan metabolit sekunder pada ekstrak daun jelatang adalah flavonoid. Flavonoid merupakan senyawa yang mudah bercampur dengan basis air dalam minyak $(\mathrm{A} / \mathrm{M})$ karena tipe krim $\mathrm{A} / \mathrm{M}$ merupakan sistem penghantar optimal untuk senyawa sekunder flavonoid (Juwita, Yamlean, \& Edy, 2013).

Pengujian efektivitas anti-aging dengan menggunakan skin analyzer Aram Huvis API-100. Parameter uji meliputi: pengukuran kelembaban, besar pori, dan pengukuran keriput. Pengukuran aktivitas anti-aging dimulai dengan mengukur kondisi kulit awal sebelum dilakukan perawatan. Hal ini dilakukan agar dapat melihat pengaruh krim yng digunakan dalam memulihkan kulit. Data hasil penelitian dianlisis dengan menggunakan program Statistical Product and Service Smirnov (SPSS). Data dianalisis dengan menggunakan metode Kruskal-Wallis lalu dilanjutkan dengan uji 
Mann-Whitney untuk melihat perbedaan antarformula. Pengujian ini dilakukan terhadap semua perlakuan yang diperiksa setiap minggunya selama 28 hari.

Tabel 2 menunjukkan peningkatan kadar air, pengecilan pori-pori, dan pengurangan keriput. Data yang diperoleh selanjutnya dianalisis menggunakan uji Kruskal Wallis dan diperoleh (nilai $\mathrm{p}<0,05$ ). Hal ini menunjukkan bahwa adanya perbedaan yang signifikan antara formula dalam meningkatkan kelembaban, mengecilkan proi-pori, dan mengurangi keriput pada kulit punggung tangan sukarelawan setelah pemakaian krim ekstrak etanol daun jetalang. Kandungan air kulit sehat minimal $60 \%$ agar kulit kenyal, cerah, membuat sel cukup nutrisi sehingga kulit tetap lembut dan berfungsi baik (Lonnie \& Jeffery, 2007, p. 173). Penelitian sebelumnya menggunakan daun jelatang sebagai formulasi anti-aging dalam bentuk sediaan gel. Hasil penelitian

Tabel 2

Hasil Pengukuran Nilai Rata-rata Kadar Air, Pori, dan Keriput pada Kulit Punggung Tangan Sukarelawan Masing-masing 3 Sukarelawan dengan Jumlah 18 Sukarelawan

\begin{tabular}{ccccccc}
\hline \multirow{2}{*}{ Formula } & \multicolumn{5}{c}{ Kelembaban } & $\%$ \\
\cline { 2 - 7 } & Kondisi Awal & 7 Hari & 14 Hari & 21 Hari & 28 Hari & Pemulihan \\
\hline A & 19,3 & 19,7 & 19,7 & 20,0 & 20,0 & 3,4 \\
B & 22,0 & 22,0 & 22,7 & 23,3 & 23,3 & 6,0 \\
C & 28,3 & 28,7 & 29,3 & 29,7 & 30,3 & 7,1 \\
D & 30,7 & 31,3 & 32,7 & 33,3 & 34,0 & 10,9 \\
E & 33,3 & 33,7 & 35,5 & 36,0 & 37,3 & 12,1 \\
F & 19,7 & 20,7 & 21,3 & 22,3 & 23,0 & 17,2 \\
& & & Pori & & & \\
A & 23 & 23,0 & 22,7 & 22,7 & 22,0 & 4,4 \\
B & 25 & 24,7 & 23,7 & 23,3 & 22,7 & 9,3 \\
C & 30 & 29,0 & 28,0 & 27,3 & 26,3 & 12,3 \\
D & 31 & 30,0 & 28,7 & 27,0 & 26,3 & 15,0 \\
E & 31 & 29,3 & 28,3 & 27,0 & 26,0 & 16,1 \\
F & 32 & 31,3 & 30,0 & 28,7 & 27,3 & 14,6 \\
& & & Keriput & & & \\
A & 23 & 23,0 & 23,0 & 22,3 & 22,3 & 2,9 \\
B & 27,7 & 27,7 & 26,7 & 26,0 & 25,3 & 8,4 \\
C & 31 & 30,7 & 29,7 & 28,7 & 27,3 & 11,8 \\
D & 33 & 32 & 30,7 & 29,3 & 28,0 & 15,2 \\
E & 34 & 32,7 & 30,3 & 29,3 & 28,0 & 17,7 \\
F & 33 & 31,3 & 30,3 & 28,7 & 27,0 & 18,2 \\
\hline
\end{tabular}

Keterangan: A (Basis Krim atau Blanko), B, C, D, dan E Sediaan Krim Ekstrak Etanol Daun Jelatang Dengan Konsenterasi Berturut-turut 0,2\%; 0,3\%; 0,4\%; dan 0,5\% serta F: Pembanding (Krim anti-aging yang Beredar di Pasaran). 
didapatkan bahwa ekstrak etil asetat daun jelatang dapat diformulasikan dalam bentuk sediaan gel yang homogen, dengan $\mathrm{pH} 4,8-$ 5,3; viskositas 2000-2450 cps; stabil dalam penyimpanan selama 28 hari (Risnanto, 2018).

Formulasi sediaan dibuat berupa krim ditujukan agar krim dapat menyampaikan zat aktif dengan baik dan efisien yang berada di dalam sediaan dapat meresapnya ke dalam kulit (Lephart, 2016). Semakin kecil nilai pore, semakin bagus kualitas kulitnya. Semakin kecil nilai spot, kulit semakin baik yaitu pada skala 0-19. Kulit yang baik memiliki nilai wrinkle pada skala antara 0-19. Semakin kecil nilai wrinkle, kualitas kulit semakin baik (Aramo, 2012, p. 24). Jika kulit sering terkena sinar matahri secara terus menerus, dapat membuat poripori semakin membesar karena sel-sel kulit mati menumpuk (Bogadenta, 2012, p. 15). Kolagen sangat berkaitan erat dengan timbulnya kerutan atau wrinkle (Ali, Akhtar, \& Chowdhary, 2014).

Pada kulit kering distribusi air dalam stratum korneum berubah dibandingkan dengan kulit sehat terutama kadar air menurun dipermukaan kulit (Quan, 2016, p. 82). Umumnya bercak-bercak hitam muncul pada bagian tubuh yang sering terpapar sinar matahari (Bogadenta, 2012, p. 15) sehingga pembentukan melanin pada kulit semakin aktif (Sumaryati, 2012, pp, 34-
36). Selain sinar matahari, noda hitam dapat terjadi akibt pemakaian obat hormonal, contohnya kontrasepsi, kosmetik yang mengandung merkuri, dan asam salisilat, antibiotik, antiepilepsi, dan antiperadangan (Malahayati, 2010, p. 106).

Kemampuan krim dalam memberikan efek anti-aging karena ada bahan aktif yang berasal dari ekstrak daun jelatang yaitu senyawa fenolik dan flavonoid. Kedua senyawa ini dikenal sebagai senyawa yang bersifat antioksidan. Yang pernah dilakukan oleh peneliti lainnya menggunakan ekstrak daun jelatang, kadar flavonoid dan fenolik total ekstrak daun jelatang sebanyak 133,916 $\pm 12,006 \mathrm{mgQE} / \mathrm{g}$ dan $322,941 \pm 11,811$ $\mathrm{mg} / \mathrm{g}$. Ekstrak daun jelatang merupakan sumber antioksidan yang baik (Fattahi et al., 2014).

\section{SIMPULAN}

Ekstrak etanol daun jelatang dapat diformulasikan dalm bentuk sediaan krim yang homogen dengan $\mathrm{pH} 6$, tipe emulsi $\mathrm{A} / \mathrm{M}$, viskositas 28.000-34.000 cps, tidak menimbulkan iritasi, dan stabil pada penyimpanan selama 28 hari. Ekstrak daun jelatang yang diformulasikan dalam sediaan krim mampu memberikan efek antiaging pada konsenterasi terbaik yaitu pada konsenterasi $0,5 \%$ dengan meningkatkan kelembaban kulit $12,1 \%$; pori semakin kecil $16,1 \%$; dan mengurangi keriput $17,7 \%$. 


\section{DAFTAR PUSTAKA}

Aksu, M. İ., \& Kaya, M. (2004). Effect of usage Urtica dioica L. on microbiological properties of sucuk, a Turkish dry-fermented sausage. Food Control, 15(8), 591-595.

Ali, A., Akhtar, N., \& Chowdhary, F. (2014). Enhancement of human skin facial revitalization by moringa leaf extract cream. Postepyy Dermatol Alergol, 31(2), 71-76.

Aramo. (2012). Skin and hair diagnostic system. Sungnam: Aram Huvis Korea.

Bogadenta, A. (2012). Antisipasi gejala penuaan dini dengan kesaktian rumah herbal. Jogjakarta: Buku Biru.

Fattahi, S., Zabihi, E., Abedian, Z., Pourbagher, R., Ardekani, A. M., Mostafazadeh, A., \& Akhavan-Niaki, H. (2014). Total phenolic and flavonoid contents of aqueous extract of stinging nettle and in vitro antiproliferative effect on hela and BT-474 Cell lines. International journal of molecular and cellular medicine, 3(2), 102-107.

Ferguson, S. (2011). Eastern European beauty secrets and skin care techniques: A practical manual for skin care professionals. Pennsylvania: RoseDog Books.

Jain, S., Singh, K., Parashar, A., \& Gupta, D. (2017). A drug: Urtica dioica. Journal of Drug Discovery and Therapeutics, 5(2), 17-22.

Juwita, A. P., Yamlean, P. V., \& Edy, H. J. (2013). Formulasi krim ekstrak etanol daun lamun (Syringodium isoetifolium). Pharmacon, 2(2).

Lephart, E. D. (2016). Skin aging and oxidative stress: Equol's anti-aging effects via biochemical nd molecular mechanisms. Ageing Research Reviews, 31, 36-54.

Lonnie, D. B., \& Jeffrey, L. W (2007). System analysis and design for the global enterprise ( $7^{\text {th }}$ ed.). New York: McGrawHill.

Malahayati. (2010). Solusi murah untuk cantik sehat energik. Yogyakarta: Great Publisher.

Martin, A., Awabrick, J., \& Cmmarat, A (2012) Farmasi fisik dasar-dasar farmasi fisik dalam ilmu farmasetik. Jakarta: Universitas Indonesia.

Muliyawan, D., \& Suriana, N. (2013). A-Z tentang kosmetik. Jakarta: PT. Elex Media Komputindo.

Mustikawati. (2017). Anatomi dan fisiologi untuk keperawatan. Jakarta: CV. Trans Info Media.

Pareetha, J. P., \& Karthika, K. (2009). Cosmeceuticals-an evolution. International Journal of ChemTech Research, 1(4), 1217-1223.

Quan, T. (2016). Molecular mechanisms of skin aging and age-related diseases. USA: CRC Press.

Rahmawati, D., Sukmawati, A., \& Indrayudha, P. (2015). Formulasi krim minyak atsiri rimpang temu giring (Curcuma heyneana val \& zijp): Uji sifat fisik dan daya antijamur terhadap candida albicans secara in vitro. Majalah Obat Tradisional, 15(2), 56-63.

Risnanto. (2018). Formulasi gel anti-aging ekstrak etil asetat daun jelatang (Urtica dioica L.) (Skripsi tidak diterbitkan). Fakultas Farmasi Universitas Sumatera Utara, Medan.

Rodriguez-Fragoso, L., Reyes-Esparza, J., Burchiel, S. W., Herrera-Ruiz, D., \& Torres, E. (2008). Risks and benefits of commonly used herbal medicines in Mexico. Toxicology and Applied Pharmacology, 227(1), 125-135.

Saad, B., \& Said, O. (2011). Greco-Arab and Islamic herbal medicine: Traditional system, ethics, safety, efficacy, and regulatory issues. New Jersey: John Wiley \& Sons. 
Shailajan, S., Hande, H., Singh, D., \& Tiwari, B. (2014). Estimation of ursolic acid from Urtica dioica $\mathrm{L}$. using validated HPTLC method. Journal of Applied Pharmaceutical Science, 4(5), 92.

Shofyana, \& Zulkarnain. (2013). Stabilitas fisik dan aktivitas krim W/O ekstrak etanolik buah Mahkota Dewa [Phaleria macrocarph(scheff.) Boerl] sebagai tabir surya. Traditional Medicine Journal, 18(2), 109-117.

Sumaryati, E. (2012). Senam kecantikan dan antipenuaan. Yogayakarta: Citra Media.
Swatika, A., Mufrod, \& Purwanto. (2013). Antioksidan activity of cream dosage from of tomato extract (Solanum lycopersicum L). Traditional Medicine Journal, 18(3), 132-140.

Zeipiņa, S., Alsiņa, I., \& Lepse, L. (2014). Stinging nettle-the source of biologically active compounds as sustainable daily diet supplement. Research for Rural Development, 20, 34-38. 